\title{
Political and Dramatic Perspectives on Archaic Sculptures: Bacchylides' Fourth Dithyramb (Ode 18) and the Treasury of the Athenians in Delphi*
}

\author{
Lucia Athanassaki
}

Bacchylides' Fourth Dithyramb dramatizes the dialogue between Aegeus and a group of Athenian youths which is prompted by the news of the imminent arrival of a hero whose outstanding bravery causes them fear and awe, as his identity and intentions are as yet unknown to them. Aegeus enumerates the unknown hero's amazing feats, reported by a messenger who has just come from the Isthmus: the prodigiously strong hero has overcome Sinis, the sow of Cremmyon, Sciron, Cercyon, and Procoptas/Procrustes (16-30). The Athenian youths express the view that a god must drive him on so that he can punish the unjust, thus alluding to his future accomplishments.

The deeds of Theseus had long been a favorite subject of story-tellers, poets, painters and sculptors. The Bacchylidean dithyramb, however, is our earliest extant literary source for the deeds of Theseus on his way from Troezen to Athens. ${ }^{1}$ In what follows I discuss the points of contact and contrast between

* This is a bibliographically updated version, at many points condensed, at other points expanded with further documentation, of sections of a book written in Greek (Athanassaki [2009]). Oral versions have been delivered at the first Network conference held at Corpus Christi College, Oxford (2008), at the University of Texas at Austin (2009) and at Reed College (2009), and at the summer seminars of the European Centre of Delphi for Argentinian and Brazilian classicists $(2010,2011)$. I am grateful to the audiences of all those occasions for stimulating discussions, helpful comments and suggestions and in particular to Rosina Colonia, Thomas Hubbard, Richard Martin, Ellen Millender, Anastasia-Erasmia Peponi, Ian Rutherford and Oliver Taplin; to Ewen Bowie, Vanessa Cazzato, John Marincola and H. Alan Shapiro for comments and suggestions on this version. Finally, many thanks to Ms. Calliope Christophi of the École française d'Athènes for photographs and permissions (figs 2, 3, and 4) and to the 1oth Ephorate of Prehistorical and Classical Antiquities for their permission to take photographs of the current exhibit of the metopes of the Athenian Treasury in the Delphi Museum (figs 5 and 6 ) at a time when it was not open to the general public.

1 Simonides sang of Theseus too. The few lines that have survived relate his voyage to Crete (Plutarch, Theseus $17=P M G 55^{\circ}$ ), but he may have sung of Theseus' early deeds as well. Aristotle in the Poetics (8) and Plutarch in the Life of Theseus mention an epic Theseis. Some

(C) LUCIA ATHANASSAKI, 2016 | DOI: 10.1163/9789004314849_003

This is an open access chapter distributed under the terms of the Creative Commons AttributionNoncommercial 3.0 Unported (CC-BY-NC 3.0) License. 
Bacchylides' song-dance and the sculptural theme of the south metopes of the Athenian Treasury in Delphi which, like the dithyramb, focus on Theseus' arrival in Athens and feature an almost identical sequence of Theseus' deeds on his way from Troezen. I argue that Bacchylides consciously evokes the metopes of the Athenian Treasury and offers a new perspective on the monument through a song that draws its inspiration from Athenian politics, tragedy, and the ambitious architectural program of Cimonian Athens.

In Section 1.1 I set out my approach to the interaction of song and image which is based on evidence showing (a) the poets as engaged and creative viewers, (b) the fascination that Delphic architectural sculpture exercised on melic poets and dramatists throughout the fifth century, and (c) viewers'/listeners' tendency to correlate verbal and visual representations. In 1.2 I compare the Bacchylidean composition with the iconography of the Athenian Treasury in terms of theme and narrative style from a listener's/viewer's point of view, with emphasis on the contrast between the human and the divine perspective that differentiate the focal scenes of the verbal and sculptural narrative. Through further comparison of the dithyramb with vases from Attic workshops I argue that the most significant departure of the Bacchylidean dithyramb from visual representations is its dramatization of human alarm and fear at the advent of the prodigiously strong hero. In Section 2 I discuss (a) Bacchylides' evocation of the Athenian Treasury in the light of Theseus' prominence in the art, cult and politics of Cimonian Athens, and (b) the political significance of ignorance and fear of the motives and intentions of the outstanding individual in the democratic polis. In Section 3 I bring the strands of my argument together and I suggest that artistically and politically the Bacchylidean dithyramb played to Athenian tastes, sensitivities and preoccupations: the evocation of the faraway monument in dramatic form draws its inspiration from tragedy and the monumental architecture which dominated the Athenian cultural scene in Cimonian Athens; the problematization of the reception of an outstanding individual in the polis is a political statement which, while relevant to Cimon, transcends the man and his time.

scholars thought that it was a sixth-century or even earlier epic that provided the inspiration for the sculptural representations of the Athenian Treasury and, possibly, for Bacchylides' dithyramb. See e.g. Schefold (1946), Schefold (1992) 175-183; tentatively Maehler (2004) 191193. Others have challenged the existence of an early epic and proposed instead that Aristotle and Plutarch were thinking of a later poem or poems. See in particular Francis (1990) 43-46, Walker (1995) 38-39 and 46. Whether such an epic existed or not, there can be no doubt that there were non-literary tales about Theseus' deeds. 
1.1 The Poet and His Audience(s) as Viewers of Architectural Sculpture The existence, the nature, and the degree of interaction between visual and literary representations have been subjects of intense debate. Studies that posit the dependence of the visual arts on literature occupy one end of the spectrum, whereas studies that espouse the total independence of literary and visual mediums represent the other extreme. ${ }^{2}$ In a recent discussion of the two opposing approaches to the relationship of drama with visual representations, Oliver Taplin offers a new angle. Taplin accepts the view that visual arts build their own vocabulary and that the signification of visual representations is on the whole self-sufficient. Contrary to the 'iconocentrists', however, Taplin puts forward the idea of 'enrichment', which has to do more with the experience of the viewer and less with the artistic vocabulary of the painter. On this view a visual representation means more to a viewer who knows and can therefore recall the corresponding tragic scene:

Whatever it was that the viewers wanted from mythological paintings, it was clearly not pictures of plays and not pictures of tragic performances. But, given the presence of tragic theatre in their lives, there was no reason for them to keep these two art-forms running separately along parallel lines. ${ }^{3}$

The 'enriched' experience of the viewer is the angle I adopt in my discussion of the interaction of Bacchylides' dithyrambic composition for the Athenians and the metopes of the south side of the Athenian Treasury in Delphi. Bacchylides' dithyrambs cannot be dated safely, but a number of indications point to the 470 or the 460 s for the composition and performance of this dithyramb as well as the thematically akin ode 17 . I will discuss briefly the date of the monument in the next section, but if mid-47os is a terminus post quem for the composition and performance of the dithyramb, it is certain that Bacchylides had plenty of opportunity to see the sculptural décor of the Athenian Treasury during his visits to Delphi before its composition. ${ }^{4}$ Thus I include him among the viewers,

2 For the controversy see Taplin (2007) 22-26; for the debate on viewers' attitudes to architectural sculpture see Marconi (2009). For the growing interest in the relationship between melic poetry and architectural sculpture see Marconi (2009); Athanassaki (2011) 254 with references in n. 53; Power (2011).

3 Taplin (2007) 26.

4 For an early date of composition, i.e. around 475, see e.g. Zimmermann (1989) 99 n. 27; Francis (1990) 58; Calame (1996) 153-156. 
but I consider him a special viewer who-as I will suggest—was inspired by the monument but cast his experience in a tragic mould. ${ }^{5}$

There is reason to believe that Bacchylides was an engaged viewer. His overt reference to Hieron's dedicatory offerings to the Delphic sanctuary in the epinician song that he composed for Hieron's chariot victory at Olympia in 468 (ode 3.17-22) offers such an indication:

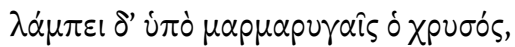

$$
\begin{aligned}
& \dot{u} \psi 1 \delta \alpha 1 \delta \dot{\alpha} \lambda \tau \omega \nu \tau \tau \mid \pi \delta \delta \delta \omega \nu \sigma \tau \alpha \theta \dot{\varepsilon} v \tau \omega \nu
\end{aligned}
$$

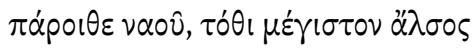

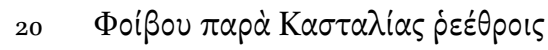

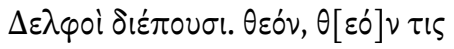

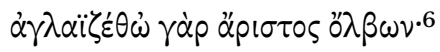

and gold shines with flashing light from the high elaborate tripods standing in front of the temple, where the Delphians tend the great sanctuary of Phoebus by the waters of Castalia. Let God, God be glorified: that is the best of prosperities.

In this instance, Bacchylides focuses on the visual effect of the ornate golden tripods on the viewer. Through the spatial specification $(\pi \dot{\alpha} \rho \circ \theta \varepsilon \nu \alpha \circ \hat{v})$, he orients his audience's mind to the particular locale in the sanctuary where Gelon's and Hieron's tripods were placed. Those who were already familiar with the temple of Apollo from previous theoric visits would recall the glittering tripods. Those who were not could easily imagine them and possibly keep a mental note to look out for them on a future visit.

The Fourth Dithyramb was composed for performance in Athens. Bacchylides could count on his Athenian audience's interest in, and familiarity with, Apollo's sanctuary. The Athenians had old and strong ties with Delphi. Their Treasury was in the immediate vicinity of the temple of Apollo, which had been brilliantly restored by the Alcmaeonids at the end of the sixth century. Athenians who visited the temple on official or private theoriai would have every reason to pay special attention to their city's Treasury. The deeds of Theseus in the metopes of the south side were their first sight of their Treasury

5 For the different responses of different viewers to monumental sculpture and vases see now Von den Hoff (2010) 162-164 and passim.

6 The Bacchylidean quotations are taken from Maehler (2004). The translations are those of Campbell (1992). 
(fig. 2.1)..$^{7}$ Not all of them, of course, would have been engaged viewers, but there is evidence showing that some of them at least would look carefully and contemplate the sights.

Two Euripidean plays, the Andromache and the Ion, offer precious glimpses into sight-seeing in Delphi. In the Andromache the messenger explains to Peleus how Orestes succeeded in convincing the Delphians that Neoptolemus came to sack the temple of Apollo. Neoptolemus' extensive and intensive sightseeing caused suspicion: the Delphians gathered to watch Neoptolemus and his retinue who were looking at the buildings and the valuable dedications of the sanctuary; his activity gave Orestes the opportunity to convince the already suspicious Delphians that the purpose of his second visit was the same as that of his first $\left(1085^{-1095)}\right)^{8}$

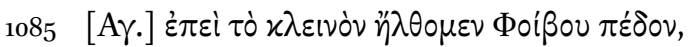

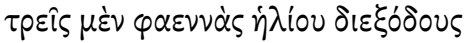

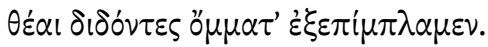

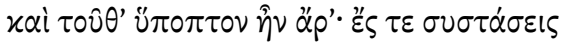

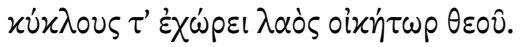

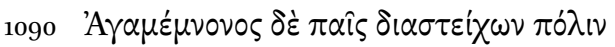

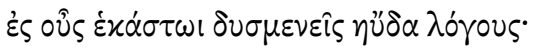

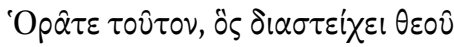

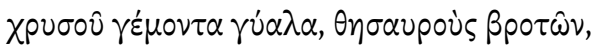

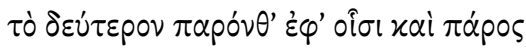

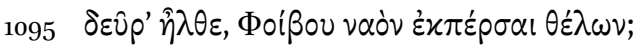

When we had come to Phoebus' glorious land, we spent three days in gazing our fill. This, it seems, caused suspicion: the people who dwell in the god's land gathered in knots and circles. The son of Agamemnon went through the city and spoke in each man's ear these hostile words: 'Do you see this man, who makes his way through the god's gold-laden precincts and the treasuries given by mortals? He has come here a second time for the same purpose as his earlier visit and means to sack the temple of Phoebus.'

7 Reconstruction of the Athenian Treasury by Tournaire (1902).

8 The text of Euripides is that of Diggle (1984) for the Andromache and Diggle (1981) for the Ion; the translations are those of Kovacs (1995) (Andromache) and Potter (1938) (Ion); they are taken from the $T L G$ and Perseus databases. 


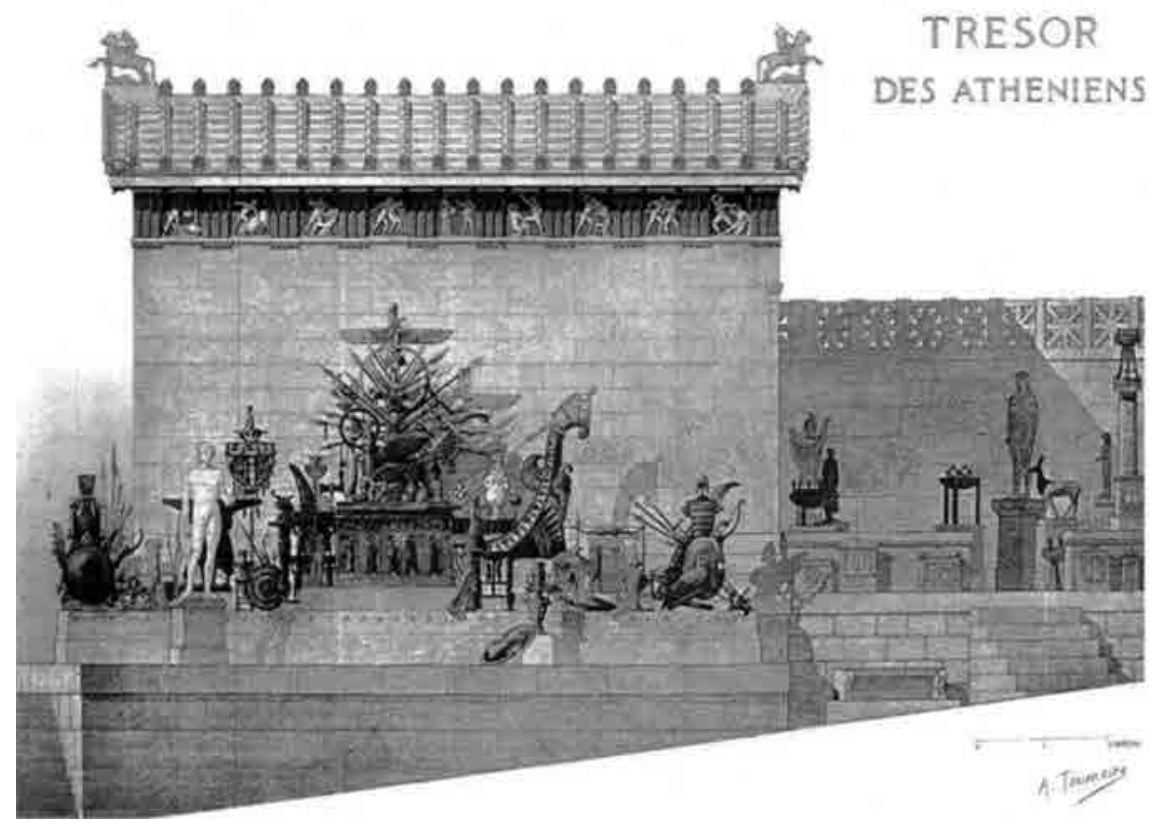

FIG 2.1 Reconstruction of the Athenian Treasury by A. Tournaire (1902)

The Athenian chorus' reaction to the sculptural decoration of the temple of Apollo in the Ion complements the picture by showing individual viewers' responses to specific representations. The fact that the chorus describes scenes that decorated the west pediment, which they could not have seen from the East side where they stood, has been pointed out and variously explained. ${ }^{9}$ Whatever explanation one gives, however, the members of the chorus are represented as engaged viewers. One viewer's response is of particular interest for our discussion (190-200):

$190-i \delta 0^{\prime}, \tau \hat{\alpha} \mathrm{l} \delta^{\prime} \ddot{\alpha} \theta p \eta \sigma o v^{\circ}$

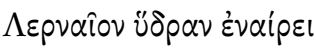

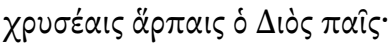

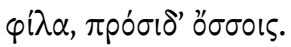

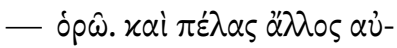

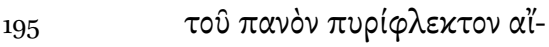

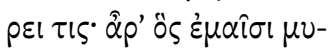

$\theta \varepsilon \dot{\varepsilon} \varepsilon \alpha \mathrm{l} \pi \alpha \rho \dot{\alpha} \pi \dot{\eta} v \alpha l \varsigma$,

9 See Zeitlin (1994) 151 and Athanassaki (2010) with the references in n. 5 . 


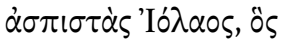

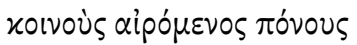 \\ 200

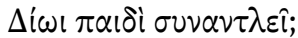

Look, look at this: Zeus' son is killing the Lernaean Hydra with a golden sickle, look there my dear. Yes - and near him another is raising on high a flaming torch. Can it be he whose story I hear as I sit at my weaving, Iolaus the shield-bearer companion of Heracles, whom he helped to endure his labors?

Stories told or sung during weaving time enable this particular viewer to venture an identification of the sculpted figure as Iolaus. The speaker does not make clear whether the story of Iolaus was simply a pastime narrative or also a theme she had woven..$^{10}$ In the latter case the tentative identification implies certain differences between the sculptural representation and her own woven version. But in either case, it is clear that the sight of the sculptural representation activates an association process whereby the viewer correlates visual and verbal variations on the same theme.

Bacchylides' mention of the effect of Hieron's golden tripods, the messenger's report in the Andromache and the chorus' vivid response to individual sculptural representations in the Ion illustrate different aspects of the viewers' intense engagement with the sights of the Apollo sanctuary. ${ }^{11}$ These are not the only overt references to the sculptural decorations and dedications at Delphi. Pindar's imaginative reconstruction of the mythical temple of Apollo featuring

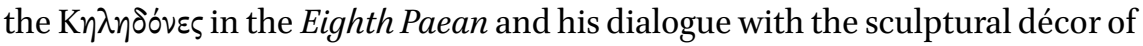
the east pediment of the temple of Apollo in the Seventh Pythian show similar engagement on the part of the viewer. ${ }^{12}$ But there are also veiled references to the sculptural themes of the Delphic temple and its treasuries. I have discussed elsewhere Pindar's variations on the sculptural theme of the Siphnian Treasury in the Sixth Pythian, the Second Olympian and the Second Isthmian. ${ }^{13}$ The Pythia's allusion to the representations of the east pediment of Apollo's temple in Aeschylus' Eumenides is yet another example of the fascination that the

\footnotetext{
$10 \quad$ For the ambiguity see Lee (1997) 180.

11 For the theoria in the Ion and the Andromache see also Rutherford (1998). On theoria in general see now Rutherford (2013).

12 For Pindar's imaginative reconstruction of the mythical temple see Marconi (2009) and Power (2011); for Pindar as a viewer of the Alcmaeonid temple see Athanassaki (2011).

13 Athanassaki (2009) 132-146, 32-37 and Athanassaki (2012).
} 
Apolline sanctuary exercised on its visitors and on the range of their engagement with its architectural sculptures. ${ }^{14}$

It goes without saying that fifth-century poets did not and need not expect every single member in their audience to be as fascinated by the sights of the temple as Neoptolemus or as excited and observant as Creusa's servants. But they could count on the fact that architectural sculpture of the Delphic sanctuary or any other Panhellenic center was a fixed and common point of reference. In Pindar's famous evaluation, song was superior to monuments and statues because, unlike sculpture, it could travel everywhere and could not be destroyed by the natural elements. ${ }^{15}$ Poets may have thought their art superior to architectural sculpture, but they engaged in dialogue with it. Its fixity may have been a disadvantage in comparison to song, but as common points of reference fixity and conspicuousness had a clear advantage over less stable, conspicuous and enduring visual representations such as those on everyday ceramic vessels.

\subsection{Theseus' Deeds: Viewing and Listening in Delphi and Athens}

The date of the monument and the date of the dithyramb have been debated, but both the high and the low dates proposed for each one do not affect their temporal relation. The monument antedates the dithyramb. The archaic style of the metopes of the south side has led a number of scholars to date the monument no later than the first decade of the fifth century, but Pausanias tells us that the Athenians built their Treasury in Delphi after the battle of Marathon from the spoils they took from the Persian army (10.11.5). The post-490 date has long been defended by the French excavators and recent finds seem to corroborate it. ${ }^{16}$ In this case the archaic style of the sculptures is explained as the old-fashioned work of a sculptor (or sculptors) of the previous generation. ${ }^{17}$ As has already been mentioned, the date of the Bacchylidean composition is unknown. Most scholars date it to the mid- or late $470 \mathrm{os}$, but a date as late as 458 has also been proposed. ${ }^{18}$ The high date brings the dithyrambic performance

\footnotetext{
14 Plassart (1940); Athanassaki (2011) 249-252 with references.

15 For the mobility of song vs. the immobility of statues see Nem. 5.1-5 and Isthm. 2.43-46; for its greater endurance see Pyth. 6.1-17.

16 See Amandry (1998), Neer (2002) and Neer (2004). For new arguments in favor of the earlier date see now Von den Hoff (2009) and (2010).

17 See Maaß (1993) 174.

18 Post-459: Merkelbach (1973); 458 at the Panathenaea: Maehler (2004) 189-191; see also the discussion in Section 2.
} 
in Athens closer in time to the completion of the monument in Delphi, the low date brings it closer to the inception of the Hephaisteion which, like the Athenian Treasury, was also decorated with metopes representing the deeds of Theseus and Heracles. ${ }^{19}$

Song and monument tell the same story from a different perspective. To start with the monument, eight of the nine metopes of the south side of the Athenian Treasury each illustrate one famous deed in Theseus' impressive curriculum, whereas one depicts Athena welcoming him. ${ }^{20}$ According to the widely accepted reconstruction of Pierre de la Coste-Messelière the sequence from West to East is: (1) Theseus and Sinis; (2) Theseus and Procrustes or Sciron (figs 2.2 and 2.5); (3) Theseus and Cercyon (figs 2.3 and 2.5); (4) Theseus and Sciron or Procrustes; (5) Athena and Theseus (figs 2.4 and 2.5); (6) Pallas; (7) Theseus and the bull of Marathon; (8) Theseus and Minotaur; (9) Theseus and Antiope (figs 2.1 and 2.6). ${ }^{21}$

The metope featuring Theseus with Athena, which according to the reconstructed sequence separates the deeds before his arrival to Athens from his later deeds, is the only moment of relief for the young hero, the only representation that does not show him engaging with an opponent. The scene has been interpreted as Theseus' arrival in Athens and, as Jenifer Neils suggests, it forms the climax of his deeds on his way from Troezen:

19 For the Hephaisteion see below, Section 2.

20 This representation is unique in contemporary art. Elsewhere Athena is included in scenes depicting Theseus' engagement with opponents, but only here does she appear alone with Theseus. As a rule Athena appears alone only with Heracles. See Brommer (1982) 69, who suggests Theseus' status is thus elevated to that of Heracles. Morris (1992) 343 observes: 'On the Athenian treasury she represents the blessings of the city of Athens, duplicated below the building where she appears in the line-up of gods and heroes dedicated after Marathon'.

21 La Coste-Messelière (1957) 37-81. Brommer (1982) 69 proposes a slightly different order: (1) Sinis; (2) Sciron; (3) Cercyon; (4) Procrustes; (5) Athena and Theseus; (6) the Sow; (7) the Marathon Bull; (8) Minotaur; (9) Antiope; cf. Von den Hoff (2009) 99-100 and Von den Hoff (2010) 167-170, who argues in favor of Periphetes in metope 4. In the current display of the metopes at the Delphi Museum (figures 5 and 6) only the best-preserved are displayed; for the various practical considerations that led to this particular display see Colonia (2003). 


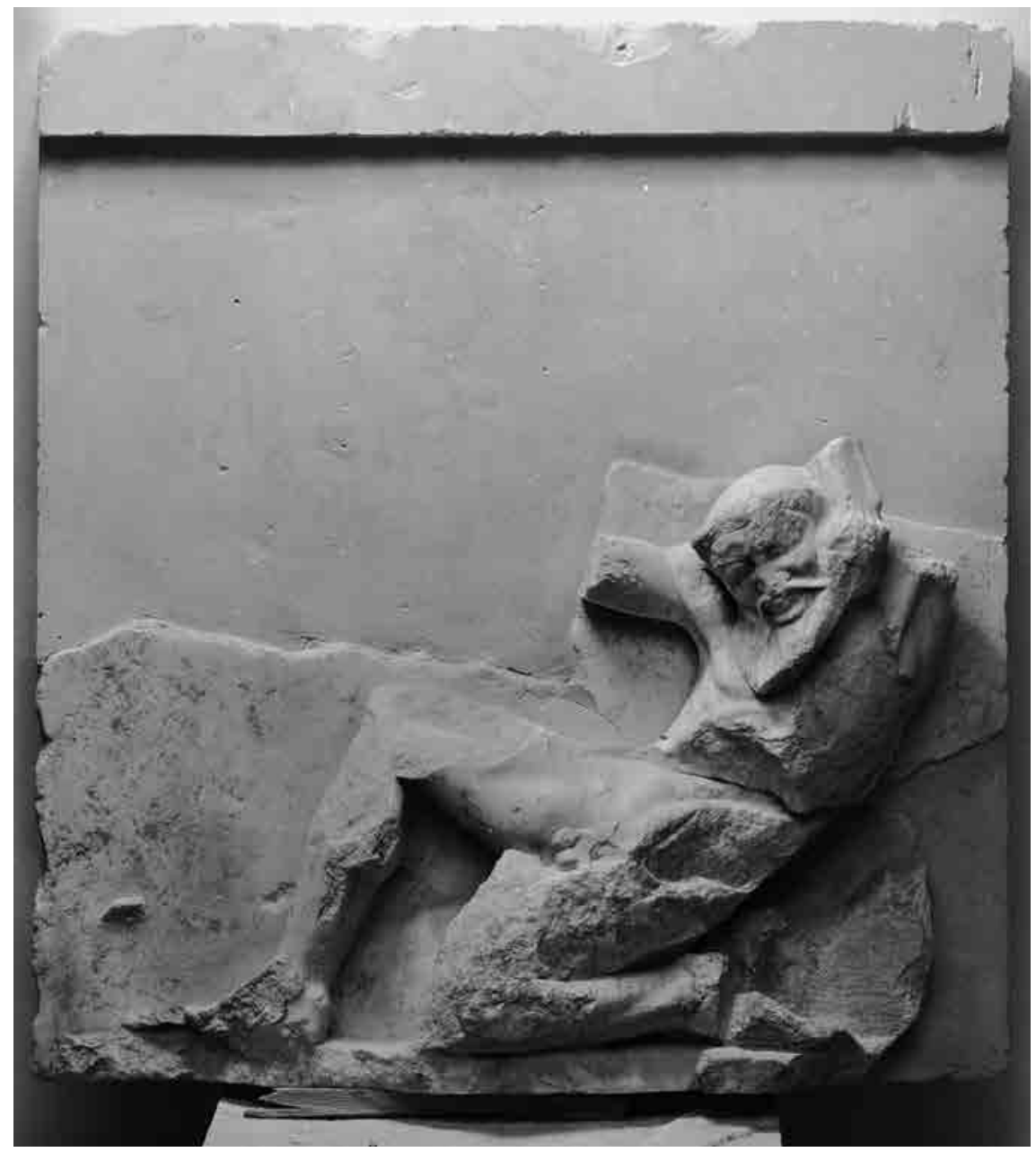

FIG. 2.2 Theseus and Procrustes or Sciron. Metope from the Athenian Treasury at Delphi, South Side, Archaeological Museum of Delphi. PHOTO 22364: ÉCOLE FRANÇAISE D'ATHÈNES/ G. DE MIRÉ 


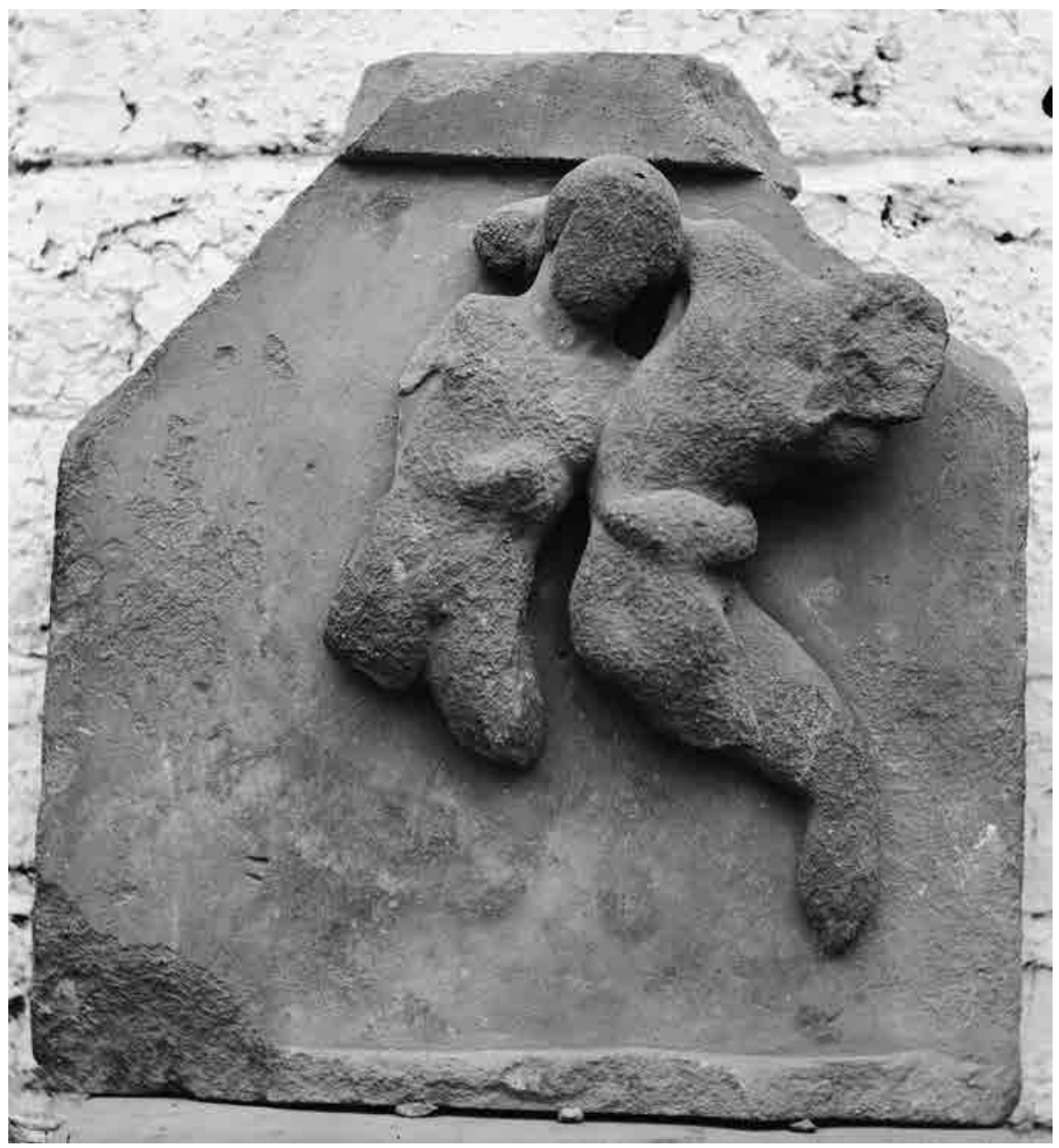

FIG. 2.3 Theseus and Cercyon. Metope from the Athenian Treasury at Delphi, South Side, Archaeological Museum of Delphi.

PHOTO CO92: ÉCOLE FRANÇAISE D'ATHÈNES 


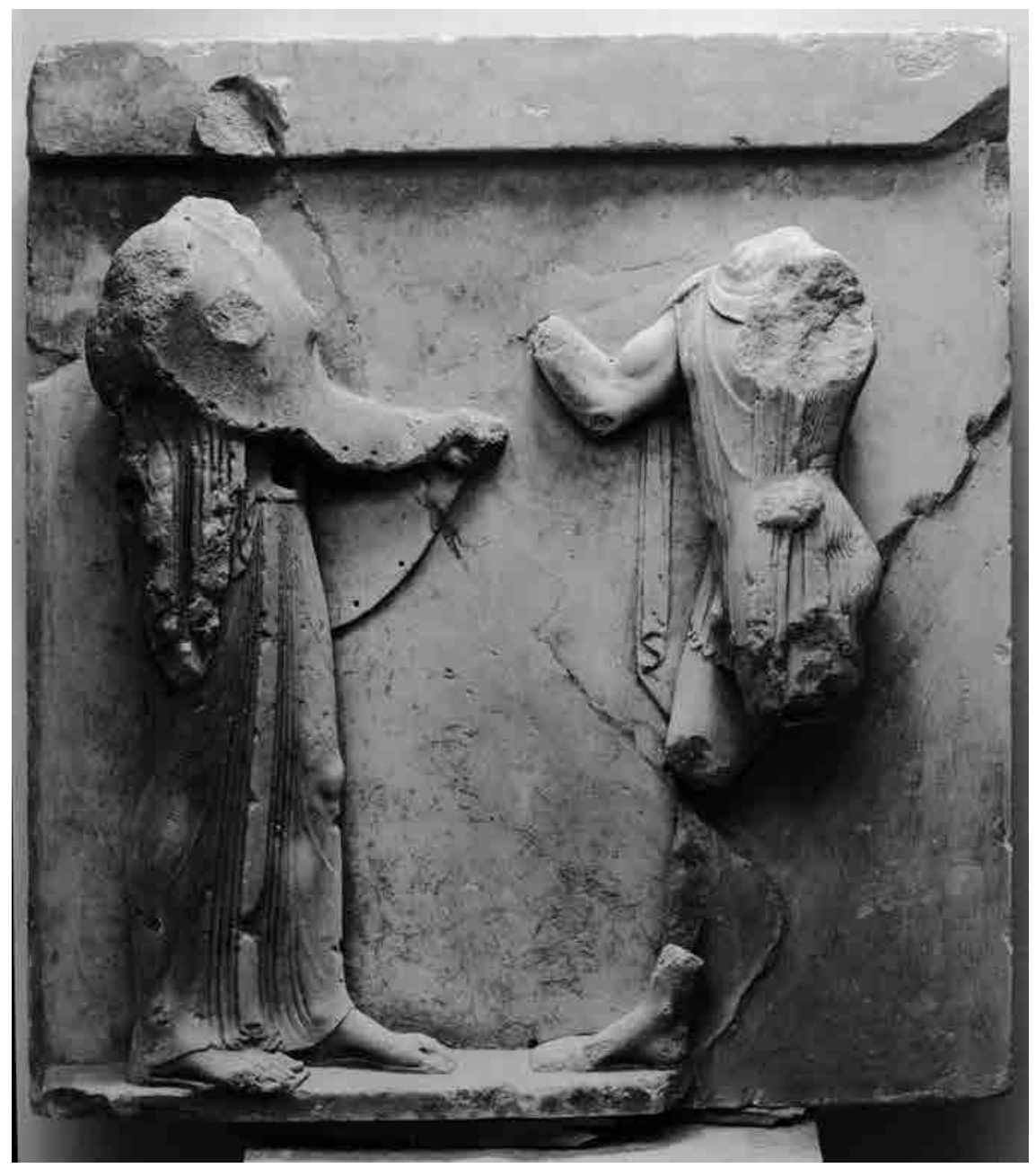

FIG. 2.4 Athena and Theseus. Metope from the Athenian Treasury at Delphi. South Side, Archaeological Museum of Delphi. PHOTO 22356: ÉCOLE FRANÇAISE D'ATHÈNES/ G. DE MIRÉ 


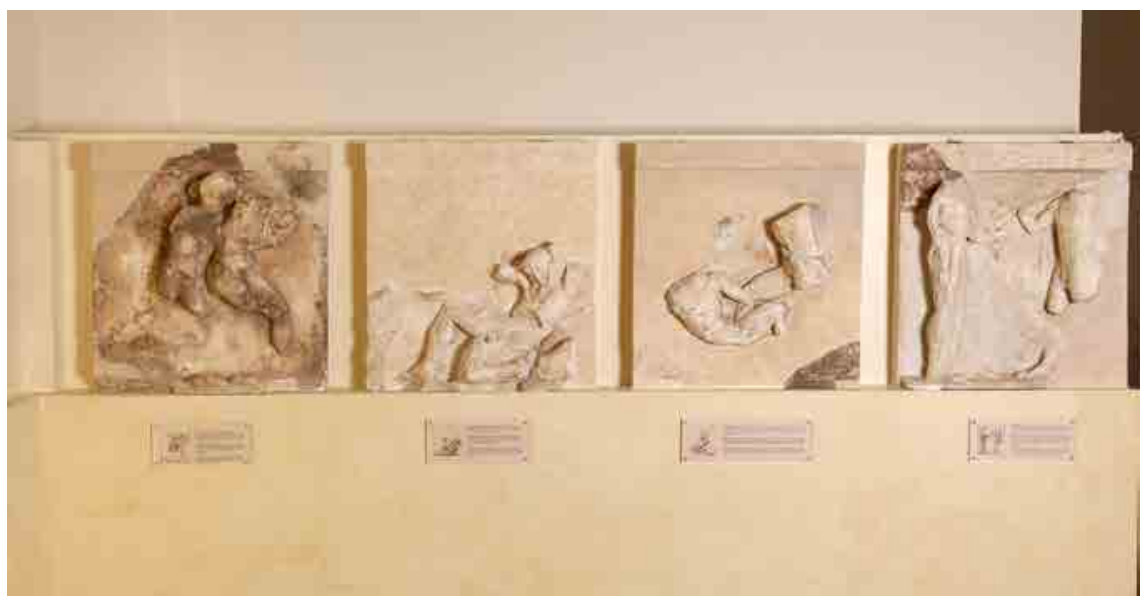

FIG. 2.5 Display of the Metopes in the Delphi Archaeological Museum PHOTO: AUTHOR's ARCHIVE

The series culminates as it does in Bacchylides' ode in the triumphant arrival of the hero into Athens, and this is precisely the subject of the fifth and central metope (...) Dubbed a 'sacra conversazione', the scene shows the goddess Athena standing immobile at the left confronting a youth who is arriving from the right. He is wearing a short chiton, traveling cloak and sandals, and rests his left hand on his hip. (...) Athena, whose Attic helmet overlaps the metope border, is no doubt holding her spear and making a welcoming gesture. ${ }^{22}$

Theseus' imminent arrival at Athens is the moment that Bacchylides chose to dramatize. Unlike the sculptor, however, who depicted the hero's meeting with the omniscient goddess, Bacchylides opted for the limited human perspective of king Aegeus and a group of young Athenians:
$\mathrm{A}^{\prime}\langle\mathrm{XOPO} \Sigma\rangle$

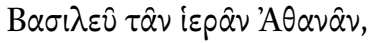

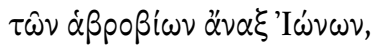

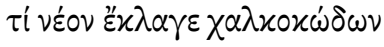 $\sigma \dot{\alpha} \lambda \pi \nu \xi \xi \pi \lambda \varepsilon \mu \eta \ddot{\alpha} \alpha \nu \dot{\alpha} \circ \delta \delta \dot{\alpha} \nu ;$

22 Neils (1987) 49. Cf. Von den Hoff (2009) 100, who argues that Athena held the helmet in her right hand. 


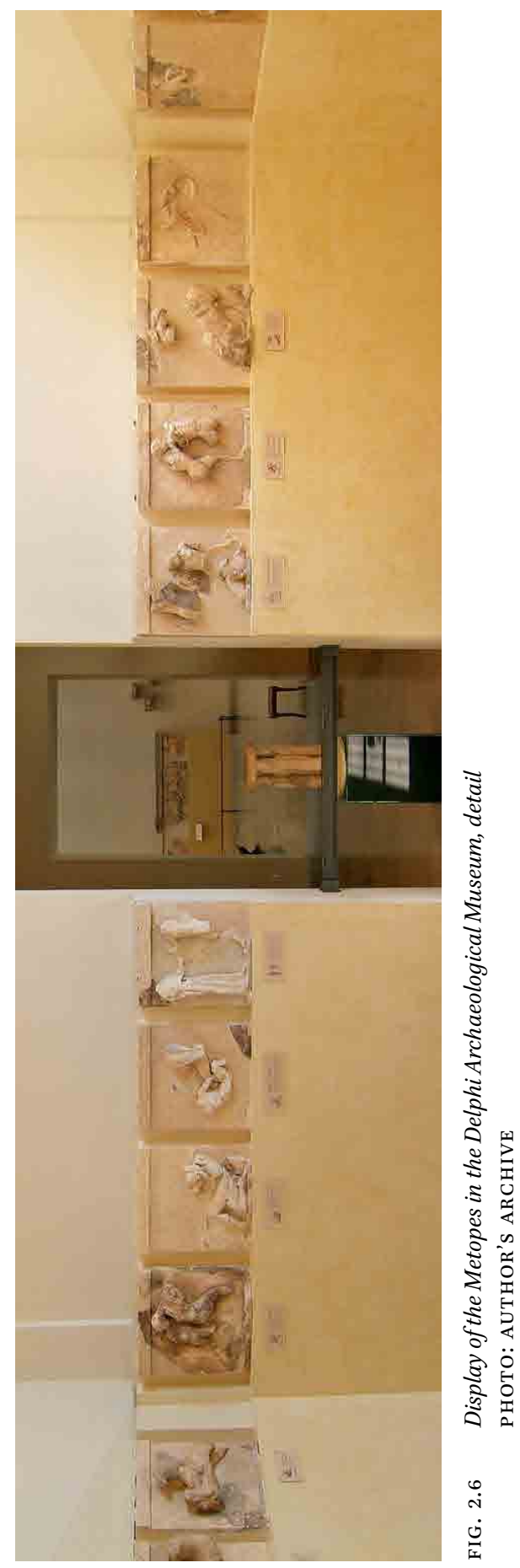


$5 \quad \hat{\eta} \tau ı \varsigma \dot{\alpha} \mu \varepsilon \tau \varepsilon \dot{\rho} \rho \varsigma \chi$ Өovò

$\delta v \sigma \mu \varepsilon v \eta \dot{s}$ öpl' $\alpha \mu \varphi$ i $\beta \alpha \lambda \lambda \varepsilon l$

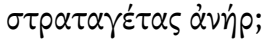

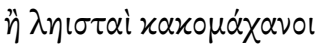

$\pi 01 \mu \varepsilon^{\prime} \nu \omega \nu \alpha \dot{\alpha} x \alpha \tau \iota \mu \eta^{\prime} \lambda \omega \nu$

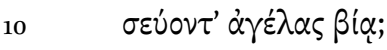

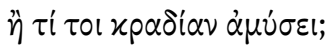

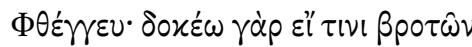

$\alpha \lambda x i \mu \omega \nu$ ह่ $\pi$ เxoupi $\alpha \nu$

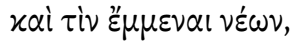

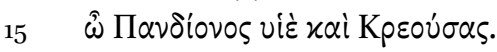

$\mathrm{B}^{\prime}\langle$ AIГEY $\Sigma\rangle$

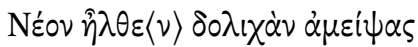

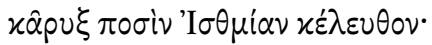

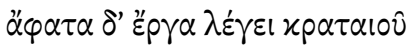

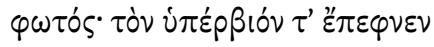

$20 \quad \sum i v i v$, ös i

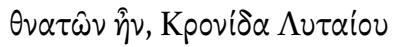

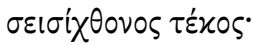

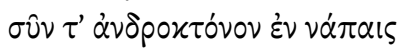

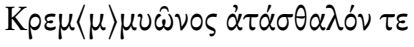

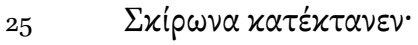

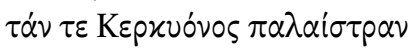

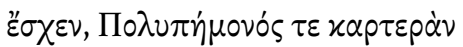

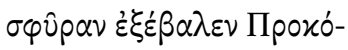

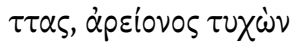

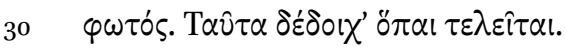

$\left.\Gamma^{\prime}\langle\mathrm{XOPO}\rangle\right\rangle$

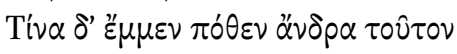

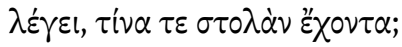

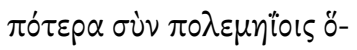

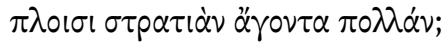

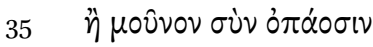

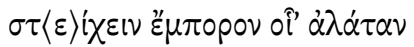

غं $\pi^{\prime} \dot{\alpha} \lambda \circ \delta \alpha \mu i \alpha \nu$,

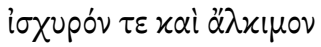

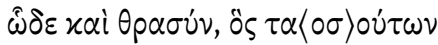

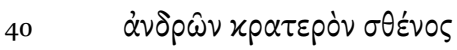


[Chorus:]

Who does he say that this man is? From where? How equipped? Does he bring a large force armed for war or travel alone with his attendants like a wanderer journeying to foreign parts, so strong, valiant and bold that he has overcome the powerful might of such great men? Truly a god must be driving him on to contrive just punishments for the unjust; for it is not easy to perform deed after deed without meeting disaster. All things come to an end in the long course of time.

\section{[Aegeus:]}

He says that only two men accompany him; he has a sword with ivory hilt slung from his bright shoulders; two polished spears in his hands, a wellmade Laconian cap about his fire-red hair, a purple tunic over his chest and a wooly Thessalian cloak; from his eyes flashes red Lemnian flame; he is a youth in his earliest manhood, and his thoughts are of the pastimes of Ares, war and the clashing bronze of battle; and he seeks splendour-loving Athens.

The most significant difference between the sculptural and the poetic narrative lies in the different perspective which the poet adopts. Unlike the sculptor who foregrounds the omniscient perspective of Athena, Bacchylides opts for the limited perspective of Aegeus and the Athenian youths who, unlike the welcoming goddess, experience fear and hope. The differences resulting from the different perspective of the dithyramb and the sculptures notwithstanding, sculptor and poet tell a strikingly similar story in terms of content and narrative manner. ${ }^{23}$ With the exception of the episode of Theseus' encounter with the sow of Crommyon, which the sculptor probably did not include in the sequence, Theseus' encounters with Sinis, Sciron, Cercyon and Procrustes are verbal and visual miniatures in paratactic sequence. ${ }^{24}$ The limited perspective that the Athenian king and youths adopt excludes the narration of Theseus' deeds after his arrival in Athens, but the chorus clearly alludes to them in

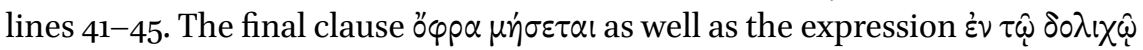
$\chi p o ́ v \omega \tau \tau \varepsilon \lambda \varepsilon i \tau \alpha l$ add a future dimension to the series of the wondrous deeds of the unknown hero, thus alluding to his future feats.

23 For Bacchylides' narrative art in general see Rengakos (2000).

24 Cf. Von den Hoff (2009) 100 with n. 41, who, like others, entertains the possibility of a metope representating the slaying of the sow of Crommyon. 
If the metope depicting Theseus' reception by Athena was originally placed in the middle of the sequence, the dialogue between song and monument is indeed most powerful. Just as in the sculptural representation, so too in the poetic version Theseus' arrival in Athens serves as the central scene from which one can look back or forward. Through the king's revelation of the messenger's report Bacchylides' audience is invited to look back. Through the young Athenians' hypothesis concerning the divine sanction of Theseus' initiatives, they are encouraged to think of those that will follow. The chorus does not know the identity of the deity that drives Theseus to punish the unjust, but as is obvious from ode 17.7 , Bacchylides, like the sculptor, is thinking of Athena.

But even if the metope was placed elsewhere in the original sequence points of contact between poem and monument would still exist, for, as Robin Osborne observes, the metopes encourage the viewer to look at them both individually and as a sequence:

Metopes are different. They are the most ambiguous of all the sculpted surfaces of a building, for they exist both individually and as a sequence. They are heavily framed by triglyphs, whose insistent vertical lines resist the motion of the eye laterally, yet their size is such that the viewers on the ground will always have more than one metope in their field of vision, always be conscious that the one metope on which they are focusing is but part of a set and requires to be compared and contrasted with its neighbours. That process of comparison establishes the expectation of links, of continuities: viewers expect to find that what is shown in one metope is, in one way or another, comparable with what is shown in the next. $^{25}$

The metope depicting Theseus' reception by Athena is a thematic variation in a sequence of eight scenes that show the hero overcoming an opponent. Osborne's observation concerning the effect of the typological repetition of the Parthenon metopes is applicable here as well:

One of the effects of having a sequence of actions by the same hero, rather than a series of episodes in a single struggle, is that the nature of the comparability between the successive scenes is quite different. For the viewer taking these in as a group, typological repetition is stressed 
much more heavily than contrast, and interest centres on the varied challenges posed to the hero. ${ }^{26}$

The typological repetition is also evident in the verbal miniatures. In each case the poet uses a variant expression denoting either the amazing strength of Theseus' opponents or the nature of their crimes, thus emphasizing his superior strength and the range of his feats. The paratactic style of the account of Theseus' deeds evokes the similarly paratactic sculptural narrative and would therefore trigger the memory of those in the audience who had seen and admired the small metopes and invite them to correlate the poetic with the sculptural version. In view of the temporal and spatial focus of the Fourth Dithyramb, an overt reference to a fairly recent building would be an anachronism, but given the importance of the Treasury for the Athenians, it is a fair assumption that Bacchylides could reasonably expect some at least, if not most, in his audience to make the association.

Visual representations of Theseus' deeds were certainly not lacking in Athens, as is evident from a great number of vases that have survived and are dated to the last quarter of the sixth and first quarter of the fifth centuries. Some of these vases represent a selective cycle of Theseus' deeds and come from Attic workshops. What has survived is presumably a minimal fraction of what was on offer. As Robert Connor observes, 'the common utensils of the dining room and kitchen bore images of his great deeds'. ${ }^{27}$ Like the metopes of the Athenian Treasury and the dithyrambic narrative, vase representations are also paratactic miniatures. ${ }^{28}$ Yet there are reasons to think that the Athenian monument in Delphi was Bacchylides' main source of inspiration and point of reference.

The most important reason has already been mentioned. The Delphic monument was a fixed and common point of reference for the poet and his audience. Whereas it is virtually certain that Bacchylides, like his audience, was familiar with various versions of the cycle of Theseus' deeds on drinking cups, amphoras, etc., such household utensils could not form the basis of a shared visual experience that the poet could take for granted. Unlike the metopes, which were a fixed sight anyone would see any time they were on their way to the Treasury or to the Temple, pots had unpredictable ownership and circulation, not to mention of course their fragility.

26 Osborne (2000) 239-240.

27 Connor (1970) 143. For the ideology of vase representations of Theseus see Shapiro (1992) and Neer (2002) 154-168.

28 For the differences between monumental and vase representations see Von den Hoff (2010). 
But there are other considerations as well. Of the extant earlier and contemporary representations only the metopes of the Athenian Treasury and the Bacchylidean dithyramb feature a sequence of deeds before and after Theseus' arrival in Athens. Bacchylides' choice to dramatize Theseus' arrival from the limited human perspective precluded of course the narration of the hero's future deeds, but, as has already been mentioned, the chorus' gnomic statement invites the audience to think of the feats that lie in store. This is not to deny, of course, that there may have been pots depicting this sequence which may have inspired the poet and/or triggered his audience's associations. Such representations, however, if they existed, could not outweigh the advantages of the Athenian Treasury as a fixed and common point of reference.

Vase representations depicting Theseus' arrival in Athens fall thematically into three categories: (a) a meeting of Theseus with Aegeus with no other figures involved; (b) a meeting of Theseus with Aegeus in the presence of other male and female figures; and (c) a meeting of Theseus with Athena either alone or with others. ${ }^{29}$ Comparison of the Bacchylidean dithyramb with all representations of Theseus' arrival in Athens falls outside the scope of this paper, but I wish to draw attention to an important difference in the representation of the human perspective by the poet and the vase painters respectively. Unlike Bacchylides, the vase painters opt on the whole for the moment of recognition and joyous reception. For instance, an amphora at the Fitzwilliam Museum in Cambridge (37.21) shows a draped man and a woman holding a phiale greeting Theseus, while a draped youth stands behind Theseus. ${ }^{30}$

The closest parallel is offered by a skyphos at the Louvre (G. 195), attributed to the Brygos painter. ${ }^{31}$ It is a cycle cup that has been interpreted by David Francis as an illustration of the very occasion for which Bacchylides composed his dithyramb. ${ }^{32}$ On the one side of the skyphos we see Theseus shaking hands with Aegeus and two women. One woman is about to crown the hero, the other holds a phiale. On the other side, which is badly preserved, art critics have identified three of Theseus' deeds on his way to Athens, namely Sinis, the Sow with Phaea, and Cercyon. Thematically the skyphos is closely related to the dithyramb and

29 LIMC s.vv. Aigeus D (Aigeus bei der Begrüßung des Theseus) and Theseus V (Theseus in Athens): A (Arrival and reception by king Aigeus).

$30 \quad A R V^{2} 580.2$, LIMC s.v. Theseus 157 with photograph.

$31 \quad A R V^{2} 381.174$, LIMC Aigeus 27, Theseus 156; see also Strawczynski (2003).

32 Francis (1990) 58. According to Francis the occasion for which Bacchylides composed this dithyramb was the Return of the bones of Theseus, or alternatively the dithyramb commemorated this event. 
Francis may be right in associating it with the occasion of the Bacchylidean performance. Yet the important difference is that the Brygos painter opted for the moment of recognition. This is the characteristic that the Brygos cup shares with other visual representations of the human reception of Theseus in Athens. The vase painters depict the welcome reception of the hero in Athens showing Aegeus shaking hands with Theseus and women crowning or embracing him. Thus, like Bacchylides, these representations foreground the human perspective on Theseus' arrival, but unlike him they do not problematize it. ${ }^{33}$

By foregrounding limited human knowledge and by dramatizing the moment before the recognition and joyful reception, the Bacchylidean dithyramb offers a different perspective by posing a different question: how would the Athenians feel if they knew only of Theseus' formidable power but not of his identity and intentions? The enriching experience that the dithyrambic songdance offers to viewers of artifacts of all forms is precisely the problematization of the cheerful and insouciant reception of the young hero that the sculptor of the Athenian Treasury and the vase-painters depict. This is a song-dance composed under the influence of the 'tragic Muse.. ${ }^{34}$

We do not know if the whole chorus impersonated in turn Aegeus and the Athenian youths, or if they conversed with one choreut who played the role of the king, or if two semi-choruses sang and danced the two parts. ${ }^{35}$ Whatever the mode of performance was, this miniature drama offered its audience dialogue, an embedded messenger-speech, re-enactment of ignorance, fear and hope,

33 Very interesting, but disputed, is the scene of the beautiful red-figure kylix of the Briseis painter in the Metropolitan Museum of Art (53.11.4, ARV 206.7, LIMC Theseus 219, 309). Heide Froning, followed by Jenifer Neils, ascribe the reception of Theseus by Athena and his crowning by Athenian women to his arrival in Athens from Troezen (Froning [1971] 4649, Neils [1987] 96-98) whereas others opt for his victorious return from Crete. See also Francis (1990) 6o, who interprets the scene as Theseus' departure for Crete with the twice seven and associates the cup with Bacchylides 17. In a recent article, Claude Calame opts for Athens and interprets the three related scenes on the sides and the tondo as the double legitimization of Theseus: a terrestrial legitimization by Athena which happens right after his arrival from Troezen and a maritime legitimization by Poseidon and Amphitrite on his way to Crete (Calame [2009a]). If the cup illustrates Theseus' initial arrival in Athens, it is an interesting thematic expansion of the sculptural theme. The young hero is received not only by the omniscient goddess, but also by a group of mortal Athenian women who already know who he is and therefore, unlike the dithyrambic chorus, do not experience fear and anxiety at the prospect of his arrival.

For the modes of performance see Zimmermann (1989) 96 with references in n. 5 . 
and irony. ${ }^{36}$ But unlike in tragic theatre, the audience did not experience either pity or fear but relief, because unlike their mythical ancestors, they knew that Theseus would save them from many more criminals.

\section{The Fourth Dithyramb in Context: The Athenian Political and Cultural Scene}

Like the date, the occasion of composition and performance are not known. The high date, i.e. mid- or late $470 \mathrm{os}$, places the performance at the time of Cimon's rising political power and military successes, whereas the low date $45^{8}$, tentatively proposed by some scholars, places the performance at the period after Cimon's ostracism. ${ }^{37}$ The dramatic form of this unique song-dance has led some scholars to the hypothesis of composition for performance at the Great Dionysia, whereas the prominent role of the Athenian youths has suggested to others a festival associated with ephebes, such as the Great Panathenaea, the Hephaesteia or the Theseia. ${ }^{38}$

The political aim of the composition has also been given various interpretations. In an ingenious if controversial article John Barron has argued that the diction of odes 17 and 18 is carefully chosen so as to invest Theseus with the characteristics of Cimon and thus highlight the similarities between the hero and the statesman who brought back Theseus' bones to Athens. According to Barron, Theseus' Laconian helmet and his Thessalian woolly cloak (oن̉ $\lambda$ ı० $\Theta \varepsilon \sigma-$ $\left.\sigma \alpha \lambda \dot{\alpha} \nu \chi \lambda \alpha \mu u^{\prime} \delta^{\prime} 53-54\right)$ echo the names of Cimon's sons Lacedaemonius, Ulius and Thessalus, the Lemnian fire in his eyes alludes to the annexation of Lemnos to Athens by Miltiades, whereas the hero's red hair may point to Cimon's Thracian origin through his mother Hegesipyle. ${ }^{39}$ Bernhard Zimmermann, who saw the ode as an encomium of Athenian power and splendor sung for the Atheni-

36 Burnett (1985) 117-123; Zimmermann (1989) 95-100.

37 According to Plutarch (Pericles 10) Cimon was recalled to Athens in 457 in acknowledgement of his good services during the Athenians' negotiations with the Spartans after the battle of Tanagra. Plutarch's testimony has met with scepticism, because Cimon did not hold any public office in Athens until the expiration of his ten-year term in 451. In an effort to make sense out of conflicting evidence, Ernst Badian, who, like others, expressed scepticism about Plutarch's testimony, raised the possibility of Cimon's recall under the condition not to stand for any public office until 451: Badian (1992) 17-19, 101-103. See also Stadter (1989) 124-125 with further references; and below p. 38 with n. 42.

38 For the various proposals see Zimmermann (1989) 99 with references.

39 Barron (1980) $1-2$. 
ans and their allies at one of the great festivals, probably the Panathenaea, felt that Barron went a little too far. ${ }^{40}$ On the contrary, Maehler conceded that the choice of Theseus' attributes may have been 'a string of strange coincidences', but entertained the idea that they may not have been. Building on Merkelbach's and Barron's insights Maehler put forward the hypothesis that the ode celebrated the victory of Athenian youths and veterans over the Corinthians at Geraneia under the command of Myronides and was performed at the Panathenaea of 458. On this view, Cimon's three sons were among the youths of Myronides' force. ${ }^{41}$

Bacchylides' evocation of the metopes of the Athenian Treasury tells us nothing about the date of performance. In the 470 s or 460 s Bacchylides may have been inspired by Cimon's impressive architectural program, in the early 450 s he may have wished to remind his audience of a monument associated with the victory at Marathon and therefore with the Philaids and create a favorable climate for Cimon's recall to Athens. ${ }^{42}$ Although neither alternative can be excluded, the evocation of the Athenian Treasury is more meaningful in the 470 s or the 460 s, when the figure of Theseus was an endless source of artistic inspiration in Athens. But regardless of the date of composition, as long as Cimon was alive his association with Theseus on the part of Bacchylides' audience seems to me inescapable, even if the echoes that Barron identified are due to a strange coincidence.

There are certainly more links between Cimon's effort to associate himself with Theseus and Bacchylides' 'Theseus' dithyrambs. Thanks to Pausanias we

\footnotetext{
$40 \quad$ Zimmermann (1989) 99 n. 27.

41 Maehler (2004) 189-191.

42 Since ostracism was an ad hominem penalty it would not affect Cimon's sons. The low date for the composition is therefore not impossible. But a 'Theseus' ode honoring Cimon's sons through the evocation of Theseus could not but honor Cimon himself and therefore create a favorable climate that would facilitate his recall. Cole (1977) has argued for a political message in the reconciliation of Orestes with the Erinyes in the Eumenides, performed in 458 , i.e. the wished-for reconciliation of Pericles with Cimon. If the Fourth Dithyramb was composed in the same year with a similar purpose, who would be the choregos? I am tempted to think of Cimon's brother-in-law Callias (II), who had good relations with Pericles during Cimon's ostracism and after his death; for Callias' relations with Pericles see Davies (1971) 258-261 and Badian (1992) 17-26. For the recall of Cimon see Stadter (1989) 124-125 with bibliographical references. In what follows I argue for an earlier date and a broader political statement and therefore against a very specific political agenda, but since a song about Theseus' arrival could certainly acquire a new meaning and purpose after Cimon's ostracism, I cannot resist the temptation to consider it an ideal song for the symposia of his friends and relatives.
} 
know that there was some thematic overlap between the mythical narrative of the Third Dithyramb (ode 17) and Micon's painting representing an episode of Theseus' voyage to Crete on one of the walls of the Theseion which was erected to house the hero's bones. Pausanias' account leaves unclear which episode Micon chose to paint. ${ }^{43}$ Thus the thematic overlap between song and painting cannot be precisely established. The temporal relation of the Bacchylidean composition and Micon's painting is also unknown. With regard to their relationship, there are three scenarios: (a) if song and painting are roughly contemporaneous, it is possible that Bacchylides had already seen the painting, in which case we have another instance of the poet drawing his inspiration from a civic monument; alternatively, he might have heard of it when he composed his song for the performance of the Ceian chorus on Delos; (b) if the painting was not yet realized, he may have heard of the theme that Cimon and the painters planned either through his own or Simonides' connexions in Athens; (c) if, finally, poet and painter worked in ignorance of each other's work and plans, it must be yet another coincidence. Even in this case, however, it is certain that they both chose a topic that was popular at the time both in Cimon's inner circle and in Athens at large.

We may now turn to the significance of the evocation of the sculptural theme of the Athenian Treasury in Cimonian Athens. ${ }^{44}$ The Athenian Treasury, built or at least lavishly decorated with the spoils that the Athenian took from the Persians, was closely associated with victory at Marathon and with its architect, Miltiades. Theseus was also associated with the battle of Marathon, for as Plutarch reports he appeared at Marathon and led the Athenians against the

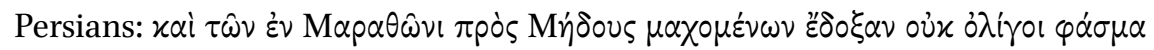

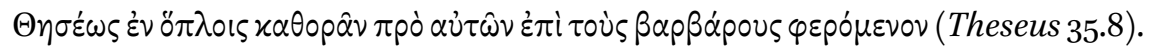
The legend was popular in Cimonian Athens and was commemorated in the Stoa Poikile:

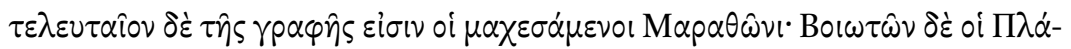

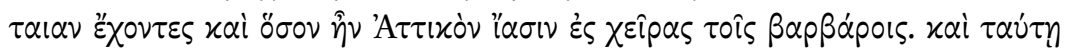

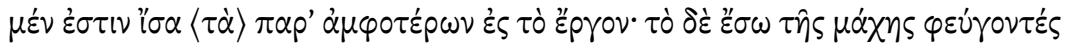

43 Pausanias reconstructs the scene on the basis of his own knowledge of the story, because time had worn the painting and Micon did not paint the whole story ( $\tau 0 \hat{v} \delta \dot{\varepsilon} \tau p i \tau o v \tau \hat{\omega} \nu$

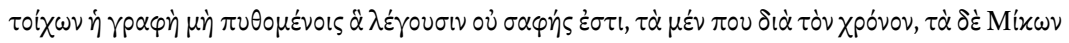

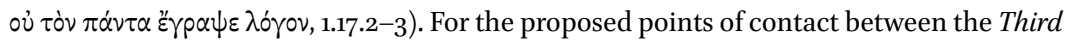
Dithyramb and Micon's painting see Athanassaki (2009) 301-304 with references.

44 For the ambitious architectural program in Cimonian Athens see Francis (1990) 43-90; Castriota (1992) 33-133. 


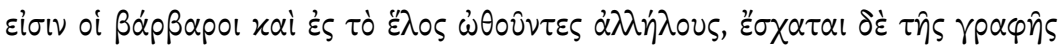

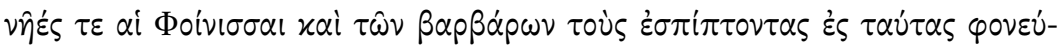

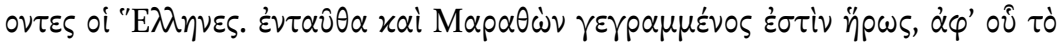

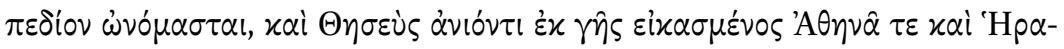

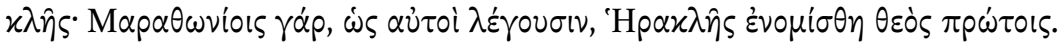

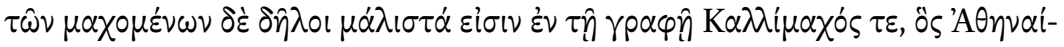

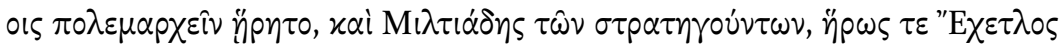

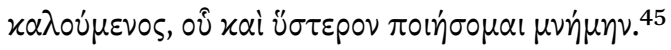

PAUSANIAS 1. $15 \cdot 3$

At the end of the painting are those who fought at Marathon; the Boeotians of Plataea and the Attic contingent are coming to blows with the foreigners. In this place neither side has the better, but the center of the fighting shows the foreigners in flight and pushing one another into the morass, while at the end of the painting are the Phoenician ships, and the Greeks killing the foreigners who are scrambling into them. Here is also a portrait of the hero Marathon, after whom the plain is named, of Theseus represented as coming up from the underworld, of Athena and of Heracles. The Marathonians, according to their own account, were the first to regard Heracles as a god. Of the fighters the most conspicuous figures in the painting are Callimachus, who had been elected commander-inchief by the Athenians, Miltiades, one of the generals, and a hero called Echetlus, of whom I shall make mention later.

The erection of the Stoa, which was funded by Peisianax, probably Cimon's brother-in-law, is dated to $475^{-45^{\circ}}$ on the basis of the pottery found at the foundation of the building. ${ }^{46}$ Once again, there is no way to establish the relation of the Bacchylidean composition with the painting. Yet the decorative program of the Stoa, like that of the Theseion, shows the Athenian interest in the monumental commemoration of Theseus' deeds and explains, in my view, why Bacchylides chose to evoke the sculptural theme and style of the faraway monument in Delphi and thus bring it to life through the chorus who sang and danced his dithyramb in Athens. ${ }^{47}$

Before turning to Bacchylides' creative dialogue with drama, it is worth bringing into the picture the similar sculptural theme and style of yet another

\footnotetext{
45 The text and translation are Spiro (1903) and Jones and Ormerod (1918).

$46 \quad$ Camp (1992) 66.

47 For the close relationship between mythical and historical past in the paintings of the Stoa Poikile see Castriota (1992) with references.
} 
Athenian building, the Hephaisteion, which is probably too late to account for Bacchylides' evocation of the Athenian Treasury, but illustrates the Athenians' admiration of and sustained interest in the Delphic monument. The metopes of the Hephaisteion evoke the metopes of the Athenian Treasury in terms of both theme and style. ${ }^{48}$ Theseus' encounter probably with Procrustes, Cercyon and the sow of Crommyon featured on the north side, Sinis, the Bull of Marathon and the Minotaur on the south side. Of course we do not know if Bacchylides knew of the intended decorative programme of the Hephaisteion. We do not know, either, if the Bacchylidean dithyramb was ever reperformed in Athens. If its premiere was successful, however, the sculptural décor of the Hephaisteion could in theory renew Athenian interest in it and enhance its chances of survival through reperformance. On the present state of the evidence, all we can say is that the Ceian poet will have been fully aware of Athenian predilection for visual representations of Theseus' deeds in Athens and Delphi. For this reason the evocation of the sculptures of the Athenian Treasury both in terms of theme and narrative style cannot but have been conscious.

The reinterpretation of the sculptural narrative in the dramatic idiom was clearly meant to heighten the popularity of the poet and his songs in a city where dramatic performances and monumental structures were at the heart of civic activity and religious life. As has already been mentioned, Cimon and his circle did not spare any effort to foreground the multiple ties of the Philaids with Theseus in Athenian art and cult. For this reason, the association of Theseus with Cimon on the part of Bacchylides' Athenian audience in the $470 \mathrm{~s}$ or the 460 os was inevitable, but it was not the only message of the dithyrambic performance.

In the Fourth Dithyramb Theseus mirrors Cimon, but I suggest that through the adoption of a dramatic, almost tragic, perspective Bacchylides formulated a far more interesting question that at once reflected contemporary politics and transcended them. Unlike sculptors and painters, Bacchylides brought out the uncertainties and the anxieties involved in the reception and accommodation of an outstanding individual in the polis. This was a question that had preoccupied Athenian politics ever since the implementation of ostracism and

48 Those who opt for inception around 460 date the metopes to the 450 ; see e.g. Neils (1987) 127 who thinks that its location in the Agora and subject matter are better suited to Cimon's than Pericles' interests. Others date the monument to 449; see e.g. Dinsmoor (1975) 179181; Boardman (1985) 146-148. For the influence of the Treasury on the Hephaisteion see e.g. Boardman (1985) 146-148, 170; Barringer (2008) 116-122 and Von den Hoff (2010), who offer comparative discussions of the metopes of the two monuments. 
which would occupy the tragic stage for many years to come. ${ }^{49}$ Sophocles, for instance, tackled the issue from different viewpoints several times in the Ajax, Trachiniae, Oedipus Rex and Oedipus Coloneus. Theseus, the archetypical Athenian statesman, could mirror more than one outstanding Athenian politician and we know that Cimon was certainly not the first Athenian leader who sought to appropriate Theseus' legacy. ${ }^{50}$ In this respect, Bacchylides' audience could associate Theseus with other prominent political figures of the present or the past. Through the dramatization of the Athenian people's ignorance and fear of the intentions of this outstanding individual Bacchylides thus made a much broader political statement. The Athenian choreuts reenacting their mythical king and ancestors legitimatized in effect the alarm and fear that citizens experience as a rule at the excessive power of individuals such as Theseus when they are either unaware or unsure of their motives and intentions. The audience's knowledge that there was no reason for fear in this case did not undermine the legitimacy of fear-it simply qualified it. The political message of the dithyramb is that people are justified in fearing immense power, but in the right hands such power can benefit the community.

As a statement on people's attitudes to outstanding individuals the Bacchylidean dithyramb offered a different perspective on the Athenians' fear and suspicion of excessive power. According to Aristotle, ostracism was first enacted because the people were suspicious that those in power might attempt to establish tyranny, as Peisistratus had done in the past. Thus in the first three years after the battle of Marathon they ostracized friends of the tyrants, but immediately afterwards they turned against anybody who was too powerful (Ath.Pol. 22. 3, 6):51

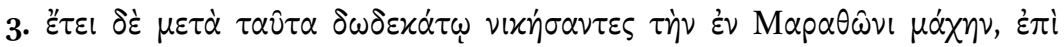

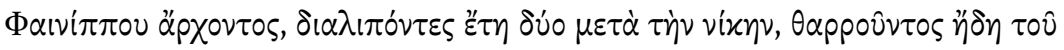

49 Recent discussion of ostracism in Forsdyke (2005) 144-177.

5o For Cleisthenes' attempt see Schefold (1946); Sourvinou-Inwood (1971) and SourvinouInwood (1979) with further documentation. See also Morris (1992) 338-341; Francis (1990) 65 , who does not deny the association of Cleisthenes with Theseus, but suggests that it 'can be most readily understood in the period immediately postdating Cimon's death, when new claims arise for the inheritance of Theseus' mantle and mythological revisionists once again set to work to rewrite history'. Shapiro (1989) 143-149 shifts the focus from the differences between the art of Cleisthenic and the Cimonian period to the similarities and argues that Theseus transcends the disputes of tyrants, oligarchs and democrats. In his view the essential difference lies in the growing interest in Theseus in Athens.

$5^{1} \quad$ Text and translation are those of Oppermann (1928) and Rackham (1952) respectively. 


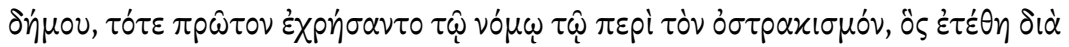

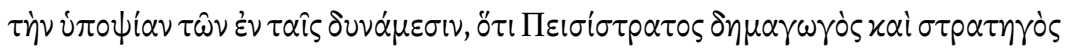

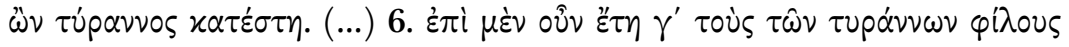

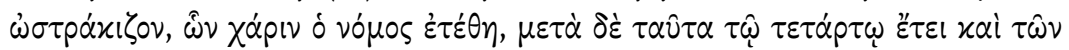

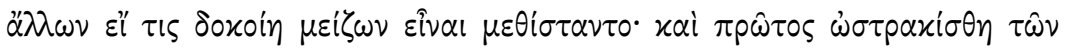

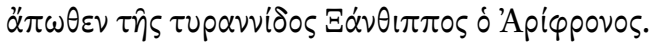

Eleven years afterwards came their victory in the battle of Marathon; and in the archonship of Phaenippus, two years after the victory, the people being now in high courage, they put in force for the first time the law about ostracism, which had been enacted owing to the suspicion felt against the men in the positions of power because Peisistratus when leader of the people and general set himself up as tyrant. (...) For three years they went on ostracizing the friends of the tyrants, at whom the legislation had been aimed, but afterwards in the fourth year it was also used to remove any other person who seemed to be too great; the first person unconnected with the tyranny to be ostracized was Xanthippus son of Ariphron.

The Bacchylidean dithyramb hit out against Athenian fear by shifting the perspective. It brought out the beneficial aspect of immense power, but significantly it did not overlook or discredit the suspicion and fear it could cause. By problematizing the representation of the welcoming reception of Theseus by sculptors and painters, Bacchylides projected contemporary issues to an idealized past, thus rendering it more complex than was hitherto represented. Seen from this new angle the past could serve in turn as a mirror of the present. Like those of contemporary leaders, Theseus' outstanding accomplishments could now be thought to have caused consternation too once upon a time, but with regard to Theseus the audience of the song-dance had the privilege of hindsight. To the extent that Theseus' attributes, deeds and reception mirrored the present, the audience was encouraged to draw analogies. Comparison of Theseus' portrayal in the song that Bacchylides composed for performance in Athens with Theseus' portrait in the Third Dithyramb, composed for the Panionian audience on Delos, to which we shall briefly turn, shows that the Fourth Dithyramb was playing to Athenian tastes, sensitivities and preoccupations.

In the Third Dithyramb Bacchylides also draws attention to the limited human perspective, but the chorus of the Ceians does not enact ignorance and fear. Minos clearly misjudges Theseus' leadership and resolution, his divine origin and Athena's favor, and sets a task for the Athenian hero that proves how 
wrong his judgment was. Like Minos, the young Ionians do not know that Theseus will accomplish the task that seems at first impossible. The Ceian choreuts, who adopt an omniscient point of view, sing of the fear which Theseus' companions experience and of the tears they shed once Theseus leaps into the sea. They also sing of their cries of joy and their paean song once he resurfaces. Unlike Aegeus and the Athenian youths, however, the sons and daughters of the Ionians are not unsure about Theseus' intentions, because in this songdance Bacchylides presents a moment after Theseus' recognition in Athens. What Theseus' companions do not know is the magnitude of his resolution and the divine favor he enjoys. Because they know his intentions, they do not fear his power, they only fear that it may not be sufficient. In this song Bacchylides chose to highlight people's anxiety and fear at the prospect of losing an outstanding leader and their joy and relief at seeing him coming back safe and triumphant. Obviously, the poet did not deem it proper to explore the dangerous side of immense power at a Panionian celebration in the first years of the Delian league. ${ }^{52} \mathrm{He}$ foregrounded its positive side and the strong emotional attachment of the Ionians to Theseus. In Athens, on the other hand, where he could take the Athenians' emotional attachment to Theseus for granted, he could afford an approach more in tune with Athenian politics, concerns and sensitivities.

\section{3}

\section{The Look of the Dithyrambic Song-Dance}

The similarity of the Fourth Dithyramb to tragedy was not only thematic but also visual and acoustic. Ignorance, hope and fear were enacted by choreuts in dialogical form. In terms of mimesis the affinities would have been greater if one choreut had enacted Aegeus and the rest the Athenian ephebes, but in any performance scenario the look of this song-dance was clearly dramatic.

I have argued that this melic drama offered a new, almost tragic, perspective on the sequence of the deeds of Theseus before and after his arrival in Athens as depicted on the metopes of the Athenian Treasury, which the choreuts brought to life through their song-dance. Bacchylides' familiarity with the temple of Apollo and the adjacent Athenian Treasury, the similarities of the visual and verbal representations in theme and narrative style, the advantages of the

$5^{2} \quad$ For the sociopolitical background of the ode see Severyns (1933) 56-59; Scodel (1984); Zimmermann (1989) 77-94; Francis (1990) 43-66; Käppel (1992) 178-189; van Overen (1999); Fearn (2007) 242; Calame (2009b); Tsagalis (2009). 
Delphic monument as a point of reference, the vested interest of the Athenians in their Treasury, and the ambitious architectural program in Athens after the Persian Wars all point to conscious evocation on the part of the poet who was a frequent visitor to Delphi and Athens. In view of the strong ties of Athens with Delphi Bacchylides could count on the familiarity of some at least in his audience with the sculptural décor of the Treasury. In the Seventh Pythian Pindar claims that in every city people talk about the Athenian restoration of the temple of Apollo. Even if we allow for encomiastic hyperbole, the assertion calls attention to what must have been a favorite pastime. Upon their return home, visitors to Panhellenic sanctuaries would describe the sights they had seen to their townsmen. ${ }^{53}$ Euripides' Ion sheds precious light on the keen interest of the theoroi in architectural sculpture. From the point of view of our discussion the identification of Iolaus by one choreut on the basis of stories she had heard at home is particularly interesting, for it shows the viewers' tendency to correlate stories they knew with visual representations and compare them, as is evident from this choreut's tentative identification of the sculpted figure.

It is therefore reasonable to assume that Bacchylides expected his audience to compare the dithyrambic version of Theseus' deeds with the sculptural version upon a future visit. If we use the chorus of the Ion as a paradigm, a viewer of the metopes who had also seen the dithyrambic performance in Athens would correlate and compare song and image and notice their main difference, namely the wholehearted reception of Theseus by Athena vs. the alarm and fear that his imminent arrival had caused Aegeus and the Athenians. I have suggested that the different perspective of the dithyrambic composition would enrich the experience of the viewer, who, like the poet, would be encouraged to ponder the complications of great power when human ignorance is factored into the picture of divine omniscience. Those who associated Theseus with Cimon would think that Athena's favor did not always guarantee smooth sailing. Such thoughts could come to one's mind both at the time of his rising power, for there were many such precedents in Athenian politics, and even more so at the time of his ostracism. Despite the inescapable association of Theseus with Cimon, however, Bacchylides' main focus was not on Cimon but on Theseus, the archetypical Athenian statesman. By projecting contemporary concerns onto the archetypical statesman, the poet had composed a song that offered the human perspective on the reception and integration of any outstanding individual in the past, the present, and the future. 
The viewer of the metopes focusing on the reception of Theseus by Athena was invited to look back at Theseus' feats on his way to Athens from Troezen and forward to what lay in store for the young hero. Like the sculptor, Bacchylides used Theseus' arrival in Athens as his focal point, thus enabling his audience to think that with Athena's favor Theseus had still many deeds to accomplish. For this reason, despite its dramatic look and tragic outlook, the Bacchylidean song-dance remained melic at its core.

\section{Works Cited}

Amandry, P. (1998). 'Notes de topographie et d'architecture delphiques. x. Le 'socle marathonien' et le trésor des Athéniens', $B C H$ 122: 75-90.

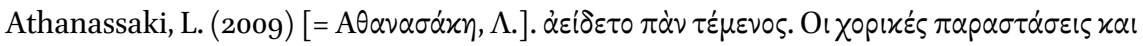

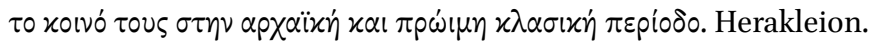

(2010). 'Performing myth through word, deed, and image: The Gigantomachy in Euripides' Ion', in A.M. Gonzalez de Tobia (ed.), Mito y Performance. De Grecia a la Modernidad. Quinto Coloquio Internacional. Acta. La Plata: 199-242.

- (2011). 'Pindar's Seventh Pythian, the Alcmaeonid Temple, and the politics of performance', in L. Athanassaki and E. Bowie (eds), Archaic and Classical Choral Song: Performance, Politics \& Dissemination. Berlin: 221-254.

- (2012). 'Performance and reperformance: The Siphnian Treasury evoked', in P. Agócs, C. Carey and R. Rawles (eds), Reading the Victory Ode. Cambridge: 134157 .

Badian, E. (1992). From Plataea to Potidea. Studies in the History and Historiography of the Pentecontaetia. Baltimore.

Barringer, J.M. (2008). Art, Myth, and Ritual in Classical Greece. Cambridge.

Barron, J.P. (1980). 'Bakchylides, Theseus and a woolly cloak', BICs 27: 1-8.

Boardman, J. (1985). Greek Sculpture. The Classical Period. London.

Brommer, F. (1982). Theseus. Die Taten des griechischen Helden in der antiken Kunst und Literatur. Darmstadt.

Burnett, A.P. (1985). The Art of Bacchylides. Cambridge, MA.

Calame, C. (1996). Thésée et l'imaginaire athénien. Lausanne.

- (2009a). 'Thésée l'Athénien au Metropolitan Museum of Art de New York: scènes étiologiques de légitimation et questions de méthode', in D. Yatromanolakis (ed.), An Archaeology of Representations: Ancient Greek Vase-Painting and Contemporary Methodologies. Athens: 98-127.

(2009b). 'Apollo in Delphi and in Delos. Poetic performances between paean and dithyramb', in L. Athanassaki, R.P. Martin and J.F. Miller (eds), Apolline Politics and Poetics. Athens: 169-197. 
Camp, J.M. (1992). The Athenian Agora. Excavations in the Heart of Classical Athens. London

Campbell, D.A. (1992). Greek Lyric, IV: Bacchylides, Corinna, and Others (Loeb Classical Library). Cambridge, MA.

Castriota, D. (1992). Myth, Ethos, and Actuality. Official Art in Fifth-Century B. c. Athens. Wisconsin.

Chaniotis, A. (2006). 'Rituals between norms and emotions: Rituals as shared experience and memory', in E. Stavrianopoulou (ed.), Ritual and Communication in the Greco-Roman World. Kernos supplément 16. Liège: 211-238.

Cole, J.R. (1977). 'The Oresteia and Cimon'. HSCPh 81: 99-111.

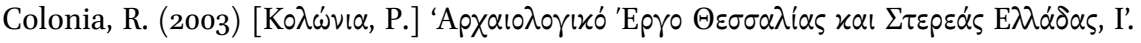

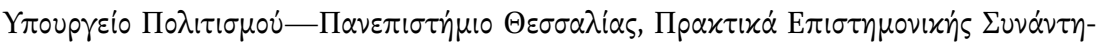
ons. Bó̀os

Connor, W.R. (1970). 'Theseus in Classical Athens', in A.G. Ward (ed.) The Quest for Theseus. London: 143-174.

Davies, J.K. (1971). Athenian Propertied Families. 6oo-30o B.c. Oxford.

Diggle, J. (1981) Euripidis fabulae, vol. 2. Oxford.

- (1984). Euripidis fabulae, vol. 1. Oxford.

Dinsmoor, W.B. (1975). The Architecture of Ancient Greece. London.

Fearn, D.W. (2007). Bacchylides. Politics, Performance, Poetic Tradition. Oxford.

Forsdyke, S. (2005). Exile, Ostracism, and Democracy. Princeton.

Francis, E.D. (1990). Image and Idea in Fifth-Century Greece. London.

Froning, H. (1991). Dithyrambos und Vasenmalerei in Athen. Würzburg.

Jones, W.H.S., and Ormerod H.A. (1918). Pausanias. Pausanias' Description of Greece, IIV. Cambridge, MA.

Käppel, L. (1992). Paian. Studien zur Geschichte einer Gattung. Berlin.

Kovacs, D. (1995). Euripides, II: Children of Heracles. Hippolytus. Andromache. Hecuba. Cambridge, MA.

La Coste-Messelière, P. de (1957). Fouilles de Delphes, IV/4: Sculptures du Trésor des Athéniens. Paris.

Lee, K.H. (1997). Euripides. Ion. Warminster.

Maaß, M. (1993). Das Antike Delphi. Orakel, Schätze und Monumente. Darmstadt.

Maehler, H. (2004). Bacchylides. A Selection. Cambridge.

Marconi, C. (2009). 'Early Greek architectural decoration in function', in D.B. Counts and A.S. Tuck (eds), Koine. Mediterranean Studies in Honor of R. Ross Holloway. Oxford: 4-17.

Merkelbach, R. (1973). 'Der Theseus des Bakchylides', ZPE 12: 56-62.

Morris, S.P. (1992). Daidalos and the Origins of Greek Art. Princeton.

Neer, R.T. (2002). Style and Politics in Athenian Vase-Painting. Cambridge.

Neer, R.T. (2004). 'The Athenian Treasury in Delphi and the material of politics', ClAnt 23: 63-93. 
Neils, J. (1987). The Youthful Deeds of Theseus. Rome.

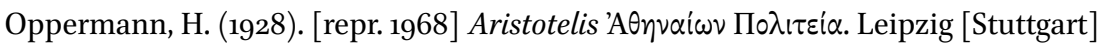

Osborne, R. (2000). 'Archaic and classical Greek sculpture and the viewer', in N.K. Rutter and B.A. Sparkes (eds), Word and Image in Ancient Greece. Edinburgh: 228-246.

Plassart, A. (1940). 'Eschyle et le temple delphique des Alcméonides', REA 42: 293-299.

Potter, R. (1938). Euripides. The Complete Greek Drama, edited in two volumes by W.J.

Oates and E. O'Neill, Jr. vol. ı. Ion, translated by Robert Potter. New York.

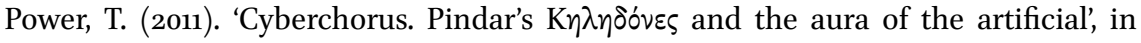
L. Athanassaki and E. Bowie (eds) Archaic and Classical Choral Song: Performance, Politics \& Dissemination. Berlin: 67-113.

Rackham, H. (1952). Aristotle in 23 Volumes, xx. Cambridge, MA.

Rengakos, A. (2000). 'Zu Bakchylides' Erzähltechnik', in B. Zimmermann (ed.), Bakchylides. 10o Jahre nach seiner Wiederentdeckung. Munich: 101-112.

Rutherford, I.C. (1998). 'Theoria as theater: Pilgrimage in Greek drama', Leeds Latin Seminar 10: 131-156.

- (2013). State Pilgrims and Sacred Observers in Ancient Greece: A Study of Theoria and Theoroi. Cambridge.

Schefold, K. (1946). 'Kleisthenes', $M$ H 3: 59-93.

- (1992). Gods and Heroes in Late Archaic Greek Art. Engl. transl. A. Griffiths. Cambridge.

Scodel, R. (1984). 'The irony of fate in Bacchylides 17', Hermes 112: 137-143.

Severyns, A. (1933). Bacchylide. Essai biographique. Paris.

Shapiro, H.A. (1989). Art and Cult under the Tyrants in Athens. Mainz.

_ (1992). 'Theseus in Kimonian Athens: The iconography of empire', Mediterranean Historical Review 7: 29-49.

Sourvinou-Inwood, C. (1971) [= Sourvinou, C.] 'Theseus lifting the rock and a cup near the Pithos Painter', JHS 91: 94-109.

- (1979). Theseus as Son and Stepson. A Tentative Illustration of Greek Mythological Mentality (BICs Supplement, 40). London.

Spiro, F. 1903. Pausaniae Graeciae descriptio, 3 vols. (Teubner) Leipzig.

Stadter, P. (1989). A Commentary on Plutarch's Pericles. Chapel Hill.

Strawczynski, N. (2003). 'Artémis et Thésée sur le skyphos du peintre de Brygos (Louvre G 195)'. RA 35: 3-23.

Taplin, O. (2007). Pots and Plays. Interactions between Tragedy and Greek Vase-Painting of the Fourth Century B.c. Los Angeles.

Tournaire, A. (1902). Fouilles de Delphes, II: Topographie et architecture. Relevés et restaurations. Paris.

Tsagalis, C. (2009). 'Blurring the boundaries: Dionysus, Apollo and Bacchylides 17', in L. Athanassaki, R.P. Martin and J.F. Miller (eds), Apolline Politics and Poetics. Athens: 199-215. 
van Overen, C.D.P. (1999). 'Bacchylides Ode 17: Theseus and the Delian League', in I.L. Pfeijffer and S. Slings (eds), One Hundred Years of Bacchylides. Amsterdam: 31-42. Von den Hoff, R. (2009). 'Herakles, Theseus and the Athenian Treasury at Delphi', in P. Schultz and R. von den Hoff (eds), Structure, Image, Ornament: Architectural Sculpture in the Greek World. Proceedings of an International Conference held at the American School of Classical Studies, 27-28 November 2004. Oxford and Oakville: 96104.

Von den Hoff, R. (2010). 'Media for Theseus, or: the different images of the Athenian polis-hero', in L. Foxhall, H.-J. Gehrke and N. Luraghi (eds), Intentional History. Spinning Time in Ancient Greece. Stuttagart: 161-188.

Walker H.J. (1995). Theseus and Athens. Oxford.

Zeitlin, F.I. (1994). 'The Artful Eye: Vision ecphrasis and spectacle in Euripidean theatre', in S. Goldhill and R. Osborne (eds), Art and Text in Ancient Greek Culture. Cambridge: 138-196

Zimmermann, B. (1989). Dithyrambos. Die Geschichte einer Gattung. Gōttingen 